\section{Pengembangan Multimedia Interaktif pada Pembelajaran Biologi untuk Meningkatkan Kemampuan Kognitif Siswa Kelas VII SMPLB Tunarungu}

\author{
Sri Rahmawati M
}

\section{Biology Teaching and Learning}

p-ISSN 2621 - 5527

e-ISSN 2621 - 5535

Abstract. This research is a Research and

Development ( $R \& D)$ which aims to determine the validity, practicality and effectiveness of interactive multimedia that has been developed in the material

characteristics of living things. The research and development model used in the development of interactive

multimedia for students of class VII $S M P L B-B$, refers to the ADDIE development model developed by Dick and Carry. The five main stages of the ADDIE model are Analyze, Design, Development, Implementation and Evaluations. Based on the results of the analysis of interactive multimedia learning media data that has been developed has met the criteria valid with a validity value of 4.49 , has met the practical criteria with practicality value 4.22 classified as high category, classified as effective with an increase in cognitive aspects of students based on $\mathrm{N}$-Gain scores by 0., 40 which belongs to the medium category

Keyworods: multimedia interactive, research and development, valid, practical, effective

\title{
Pendahuluan
}

Pendidikan merupakan salah satu upaya untuk mencerdaskan kehidupan bangsa dan meningkatkan sumber daya manusia. Pendidikan juga merupakan suatu kebutuhan pokok bagi setiap individu yang ingin maju, baik itu anak yang normal maupun anak yang mengalami kelainan fisik dan atau mental. Dalam UU No.20 tahun 2003 Tentang Sistem Pendidikan Nasional Bab I (Ketentuan Umum) Pasal 1 Butir 1 dijelaskan bahwa pendidikan adalah usaha sadar dan terencana untuk mewujudkan suasana belajar dan proses pembelajaran agar peserta didik secara aktif mengembangkan potensi dirinya untuk memiliki kekuatan spiritual keagamaan, pengendalian diri, kepribadian, kecerdasan, akhlak mulia, serta keterampilan yang diperlukan dirinya dalam masyarakat, bangsa dan negara (Pariatin dan Yuda, 2014). Pelayanan pendidikan dalam rangka mencerdaskan kehidupan bangsa, merupkan amanat yang tidak bisa disia-siakan, seperti yang termaktub dalam Undang-Undang Dasar 1945 pasal 31 ayat (1) menyatakan bahwa "Tiap-tiap warga negara berhak mendapatkan pendidikan". Hal ini berarti pendidikan harus dapat melayani semua warga negara termasuk anak luar biasa atau berkelainan, yaitu mereka yang mempunyai jenis kelainan/penyimpangan dalam segi jasmani, keindraan, intelektual, sosial, dan emosional, atau gabungan dari segisegi kelainan tersebut sehingga dapat dicapai perkembangan kapasitas yang optimal. Setiap manusia

Sri Rahmawati M Universitas Negeri Makassar Indonesia 
berhak memperoleh pendidikan untuk mengembangkan potensi yang ada dalam dirinya, tidak terkecuali bagi mereka yang memiliki kelainan atau kekurangan baik dari segi fisik, emosional, mental, maupun dari sosial. Pendidikan bagi para penyandang kelainan juga ditetapkan dalam UU No.20 Tahun 2003 Bab V Bagian Kesebelas mengenai Pendidikan Khusus dan Pendidikan Layanan Khusus, Pasal 32 Butir 1 yaitu : Pendidikan khusus merupakan pendidikan bagi peserta didikyang memiliki tingkat kesulitan dalam mengikuti proses pembelajaran karena kelainan fisik, emosional, mental, social, dan/atau memiliki potensi kecerdasan bakat istimewa.

Di SMPLB Tunarungu dan SLB pada umumnya keterampilan psikomotor lebih diutamakan daripada pengetahuan yang membutuhkan aspek kognitif. Kegiatan hands-on akan lebih bermakna apabila disertai dengan kegiatan minds-on. Hal tersebut terungkap dalam penelitian Wagino dalam Podjiastoeti (2012), bahwa bimbingan karir yang diberikan untuk anak tunarungu di SMPLB Tunarungu masih belum optimal, siswa belum dapat menentukan pendidikan lanjutan dan mengetahui kualifikasi pekerjaan yang ada di masyarakat. Keterampilan yang diberikan adalah pekerjaan rutin yang hanya mengutamakan keterampilan psikomotor.

Siswa tunarungu memiliki kesulitan untuk memahami konsep akademik sebagaimana mereka biasa diajarkan yaitu menggunakan sesuatu yang abstrak dengan metode ceramah. Padahal mereka sangat memerlukan sesuatu untuk memahami konsep-konsep yang berhubungan dengan masyarakat pada umumnya dimana mereka akan hidup. Pada anak tunarungu yang perkembangan kognitifnya dipengaruhi oleh perkembangan bahasa, sehingga hambatan pada bahasa akan menghambat perkembangan intelegensi anak tunarungu. Akibat ketunarunguannya maka proses pencapaian pengetahuan dan perkembangan intelegensi secara fungsional terhambat (Hallahan \& Kauffman, 2006). Aspek intelegensi yang terhambat perkembangannya ialah yang bersifat verbal, seperti merumuskan pengertian, menghubungkan, menarik kesimpulan dan meramalkan kejadian (Somantri, 2007) sedangkan aspek intelegensi berupa motorik dapat berkembang lebih cepat. Oleh karena itu diperlukan media yang dapat membantu anak tunarungu dalam proses pembelajaran, yang dapat memudahkan perkembangan intelegensi verbalnya.

Media pembelajaran merupakan suatu elemen penting dalam kegiatan pembelajaran di sekolah. Kebutuhan akan media pembelajaran tidak hanya untuk siswa yang normal saja. Siswa dengan kebutuhan khusus bahkan sangat memerlukan media pembelajaran untuk menunjang kegiatan belajar di sekolah, siswa berkebutuhan khusus seperti anak tunarungu sangat menggantungkan pada media visual untuk menerima informasi (Fajrianto, 2012). Biologi merupakan salah satu pelajaran yang diajarkan di sekolah, termasuk juga di SLB-B. Dengan keterbatasan yang dimiliki anak tunarungu akan sangat sulit menerima pelajaran apabila disampaikan dengan metode ceramah. Oleh karena itu kebutuhan media pembelajaran bagi anak tunarungu sangat tinggi. Media pembelajaran interaktif merupakan salah satu alternatif media pembelajaran Biologi untuk anak tunarungu.

Berdasarkan observasi pada pembelajaran biologi pada siswa tunarungu di SLB Negeri 1 Makassar, proses belajar mengajar IPA umumnya menggunakan media power point dengan tampilan yang seadanya. Penggunan media power point adalah hal yang umum kita temukan dalam proses belajar mengajar di kelas, hal ini disebabkan karena media power point sangat mudah dalam penggunaannya. Tidak perlu menguasai terlalu banyak ilmu komputer. Namun demikian, akan lebih baik jika mempelajarinya lebih dalam, karena fitur-fitur dalam aplikasi Microsoft Power Point sangat banyak dan juga bisa digunakan untuk merancang media pembelajaran yang bersifat interaktif sehingga proses belajar mengajar tidak menjadi monoton.

Berdasarkan permasalahan di atas, maka peneliti tertarik untuk mengadakan penelitian dengan judul "Pengembangan Multimedia Interaktif pada Pembelajaran Biologi untuk Meningkatkan Kemampuan Kognitif Siswa kelas VII SMPLB-Tunarungu”. 


\section{Metode Penelitian}

\section{Jenis Penelitian}

Penelitian ini merupakan Research and Development (R\&D). Model penelitian dan pengembangan yang digunakan dalam pengembangan multimedia interaktif untuk siswa SMPLB-B kelas VII, mengacu pada model pengembangan ADDIE yang dikembangkan oleh Dick dan Carry. Lima tahap utama dari model ADDIE yaitu Analyze, Design, Development, Implementation and Evaluations.

\section{a) Analyze (Analisis)}

Tahap analisis merupakan suatu poses need assessment (analisis kebutuhan). Pada tahap ini, kegiatan utama adalah menganalisis perlunya pengembangan media pembelajaran yang baru. Pengembangan media pembelajaran diawali oleh adanya masalah.

Pada tahap analisis dilakukan analisis siswa, analisis teknologi, dan analisis kurikulum yang sesuai dengan karakteristik kebutuhan siswa kelas VII SLB Negeri 1 Makassar.

\section{b) Design}

Tahap ini dikenal dengan istilah membuat rancangan (blue print). Tahap desain merupakan proses yang sistematik yang dimulai dari menetapkan tujuan pembelajaran, menetapkan jenis software yang akan digunakan, menetapkan siapa pengguna media, dan membuat rancangan multimedia interaktif yang akan dibuat.

\section{c) Development}

Tahap pengembangan (development) merupakan proses mewujudkan rancangan yang telah dibuat. Kegiatan pada tahap ini meliputi kegiatan pengumpulan bahan/materi media pembelajaran berbasis multimedia interaktif, pengetikan, dan lain-lain.

\section{d) Implementation}

Tahap implementasi (implementation) merupakan tahap penerapan media dalam pembelajaran di dalam kelas. Hasil pengembagan terlebih dahulu diperiksa oleh validator sebelum diterapkan dalam pembelajaran di kelas.

\section{e) Evaluation}

Tahap evaluasi adalah proses untuk melihat kevalidan, kepraktisan dan keefektifan dari media yang telah dikembangkan. Tahap evaluasi bisa dilakukan pada setiap empat tahap di atas, yang disebut evaluasi formatif, karena tujuannya untuk kebutuhan revisi.

Teknik analisis data yang digunakan pada penelitian ini yaitu analisis statistik deskriptif.

\section{Analisis kevalidan}

Menurut Hobri (2010), berdasarkan data hasil penilaian kevalidan media dari beberapa ahli yang kompeten dalam bidangnya ditentukan rata-rata nilai indikator yang diberikan masing-masing validator. Berdasarkan rata-rata nilai indikator ditentukan rerata nilai untuk setiap aspek. Nilai rata-rata total aspek yang dinilai ditentukan berdasarkan rata-rata untuk setiap aspek penilaian. Kegiatan penentuan nilai rata-rata total aspek penilaian kevalidan media mengikuti langkah-langkah berikut.

1. Melakukan rekapitulasi data penilaian kevalidan media ke dalam tabel yang meliputi: aspek (Ai), indikator (Ii), dan nilai (Vji) untuk masing-masing validator yang meliputi validator ahli media, ahli materi atau isi mata pelajaran.

2. Menentukan rata-rata nilai hasil validasi dari semua validator untuk setiap indikator dengan rumus:

dimana,

$$
I i=\frac{\sum_{j=1}^{n} V j i}{n}
$$

$\mathrm{I} i=$ rerata untuk aspek ke- $i$ indikator ke- $j$,

$\mathrm{V} j i \mathrm{i}=$ data nilai validator ke- $j$ terhadap indikator ke- $i$, 
$\mathrm{n} \quad$ =adalah banyaknya validator

hasil yang diperoleh kemudian ditulis pada kolom dalam tabel yang sesuai.

3. Menentukan rerata nilai untuk setiap aspek dengan rumus:

dimana,

$$
A i=\frac{\sum_{j=1}^{n} \text { Iif }}{m}
$$

$A i$ = rerata nilai untuk aspek ke- $i$,

$\mathrm{I} i j=$ rerata untuk aspek kei-i indikator ke- $j$,

$\mathrm{m}$ = banyaknya indikator dalam aspek ke- $i$

hasil yang diperoleh kemudian ditulis pada kolom dalam tabel yang sesuai.

4. Menentukan nilai Va atau nilai rerata total dari rerata nilai untuk semua aspek dengan rumus:

dimana,

$$
V a=\frac{\sum_{i=1}^{n} A i}{n}
$$

$\mathrm{Va}=$ nilai rerata total untuk semua aspek,

$A i$ = rerata nilai untuk aspek ke- $i$,

$n$ = banyaknya aspek

Hasil yang diperoleh kemudian ditulis pada kolom dalam tabel yang sesuai. Selanjutnya nilai Va atau nilai rata-rata total ini dirujuk pada interval penentuan tingkat kevalidan media sebagai berikut:

Tabel 1. Kategori Validitas Media Pembelajaran

\begin{tabular}{|c|c|}
\hline Nilai & Kategori \\
\hline $4.5 \leq \bar{V} \leq 5$ & Sangat Valid (SV) \\
\hline $3.5 \leq \bar{V}<4.5$ & Valid (V) \\
\hline $2.5 \leq \bar{V}<3.5$ & Cukup Valid (CV) \\
\hline $1.5 \leq \bar{V}<2.5$ & Kurang Valid (KV) \\
\hline $\bar{V}<1.5$ & Tidak Valid (TV) \\
\hline
\end{tabular}

Sumber: Hobri, 2010

Kriteria menyatakan media memiliki derajat validitas yang baik, jika minimal tingkat validitas yang dicapai adalah tingkat valid. Jika tingkat pencapaian validitas di bawah valid, maka perlu dilakukan revisi berdasarkan masukan (koreksi) validator. Selanjutnya dilakukan kembali validasi. Demikian seterusnya sampai diperoleh media yang valid.

\section{Analisis Data Kepraktisan}

Teknik analisa yang sama untuk mengukur kevalidan juga dilakukan pada penilaian tentang kepraktisan atau keterlaksanaan oleh praktisi (guru IPA) terhadap media berdasarkan persepsi dan pengalamannya, namun nilai rata-ratanya atau IP dirujuk pada interval kepraktisan media sebagai berikut:

Tabel 2. Kategori Kepraktisan Media Pembelajaran

\begin{tabular}{|c|c|}
\hline Nilai Interval & Kategori \\
\hline $1 \leq \mathrm{IP}<2$ & sangat rendah \\
\hline $2 \leq \mathrm{IP}<3$ & rendah \\
\hline $3 \leq \mathrm{IP}<4$ & sedang \\
\hline $4 \leq \mathrm{IP}<5$ & tinggi \\
\hline $\mathrm{IP}=5$ & sangat tinggi \\
\hline
\end{tabular}

Keterangan: IP adalah rata-rata kepraktisan dari praktisi 
Pengembangan Multimedia Interaktif pada Pembelajaran Biologi untuk Meningkatkan Kemampuan Kognitif Siswa Kelas VII SMPLB Tunarungu (hlm. 24-37)

Kriteria menyatakan media memiliki derajat validitas dan kepraktisan yang baik, jika minimal tingkat validitas yang dicapai adalah valid dan jika minimal tingkat kepraktisan yang dicapai adalah baik. Jika tingkat pencapaian validitas di bawah valid dan tingkat kepraktisan di bawah baik, maka perlu dilakukan revisi berdasarkan masukan dan koreksi para ahli dan praktisi.

\section{Analisis keefektifan}

Untuk membuktikan adanya peningkatan aspek kognitif siswa dengan teknik analisis data skor gain ternormalisasi. Skor gain ternormalisasi yaitu perbandingan dari skor pretest dan skor postest. Skor pretest yaitu analisis respon awal siswa (sebelum menggunakan media pembelajaran) dan skor postest respon maksimal siswa setelah menggunakan media pembelajaran (Hake, 1999). Kriteria yang digunakan untuk memutuskan bahwa media dapat meningkatkan aspek kognitif siswa adalah dengan menggunakan rumus gain ternormalisasi.

\section{Nilai N Gain $=\frac{\text { Postest }- \text { Pretest }}{\text { Jumlah Skor Maksimum-Pretest }}$}

Selanjutnya peningkatan hasil aspek kognitif siswa dapat diketahui dengan menggunakan rumus gain ternormalisasi. Adapun kategori gain ternormalisasi dapat dilihat dalam Tabel 3 berikut:

Tabel 3. Analisis Gain Ternormalisasi

\begin{tabular}{|c|c|}
\hline Indeks gain & Kategori \\
\hline $\mathrm{g}>0,70$ & Tinggi \\
\hline $0,70 \geq \mathrm{g}>0,30$ & Sedang \\
\hline $0,30 \geq \mathrm{g}$ & Rendah \\
\hline
\end{tabular}

(Sumber: Hake, Richard, R. 1999)

Berdasarkan tabel di atas, apabila skor N-Gain lebih besar dari 0,70 maka angka keefektifan yang dicapai tergolong kategori tinggi, jika skor N-Gain lebih besar dari 0,30 atau lebih kecil atau sama dengan 0,70 maka angka keefektifan yang dicapai tergolong kategori sedang, jika skor N-Gain lebih kecil atau sama dengan 0,30 maka angka keefektifan yang dicapai tergolong kategori rendah.

\section{Hasil dan Pembahasan}

\section{Hasil Penelitian}

Multimedia interaktif pada pembelajaran biologi untuk kelas VII SMPLB tunarungu telah diteliti dan dikembangkan dengan mengacu pada model pengembangan ADDIE yang terdiri dari lima tahap, yaitu Analyze, Design, Development, Implementation, dan Evaluation. Hasil dari tahap-tahap pelaksanaan penelitian ini yaitu sebagai berikut:

\section{a) Analyze (analisis)}

Tahap analisis merupakan suatu proses need assessment (analisis kebutuhan). Pada tahap ini, kegiatan utama adalah menganalisis perlunya pengembangan media pembelajaran yang baru. Pada tahap ini dilakukan analisis siswa, analisis teknologi, serta analisis kurikulum. Tahap ini menggunakan dua metode, yaitu observasi langsung dan studi literatur. Observasi langsung yaitu dengan terjun langsung ke dalam kelas untuk melihat bagaimana proses belajar mengajar IPA berlangsung pada siswa kelas VII SLB Negeri 1 Makassar. Sedangkan studi literatur yakni mencari informasi melalui buku, artikel, internet dan sumber lain yang relevan.

Analisis siswa dan teknologi dilakukan dengan melakukan observasi langsung ke lapangan dan studi literature. Berdasarkan hasil analisis siswa dan teknologi dalam pembelajaran didapatkan hasil bahwa siswa tunarungu sangat membutuhkan media dalam 
proses belajar mengajar. Media yang dimaksud adalah yang bersifat visual seperti teks, gambar dan video. Pengunaan media yang hanya berupa teks saja dapat membuat siswa menjadi cepat bosan dan lambat memahami materi pelajaran. Oleh karena itu, dibuatlah media yang menggabungkan ketiganya, yakni teks, gambar dan video. Saat ini sudah masuk era digital dimana teknologi mengalami perkembangan yang sangat pesat. Berbagi fitur-fitur aplikasi yang dapat di akses dengan mudah untuk kemudian dikembangkan sekreatif mungkin sehingga bisa dimanfaatkan untuk memaksimalkan proses belajar mengajar di kelas. Hasil analisis kurikulum seperti pada Tabel 4 berikut:

Tabel 4. Hasil Analisis Kurikulum

\begin{tabular}{|c|c|c|}
\hline Kompetensi Dasar & Indikator & Materi Pembelajaran \\
\hline \multirow{3}{*}{$\begin{array}{l}\text { 3.2 Mengidentifikasi ciri hidup dan } \\
\text { tak hidup dari benda-benda } \\
\text { dan makhluk hidup yang ada di } \\
\text { lingkungan sekitar }\end{array}$} & $\begin{array}{l}\text { 1. Mengidentifikasi ciri-ciri } \\
\text { makhluk hidup }\end{array}$ & \multirow[t]{8}{*}{ Ciri-Ciri Makhluk Hidup } \\
\hline & 2. Membuat laporan ciri-ciri & \\
\hline & 3. makhluk hidup berdasar & \\
\hline \multirow{5}{*}{$\begin{array}{l}\text { 4.2 Menyajikan hasil analisis data } \\
\text { observasi terhadap benda } \\
\text { (makhluk) hidup dan tak hidup }\end{array}$} & hasil observasi & \\
\hline & 4. Membedakan ciri makhluk & \\
\hline & $\begin{array}{l}\text { 5. hidup dan makhluk tak } \\
\text { hidup }\end{array}$ & \\
\hline & 6. Memiliki rasa ingin tahu & \\
\hline & $\begin{array}{l}\text { 7. terhadap lingkungan } \\
\text { sekitar. }\end{array}$ & \\
\hline
\end{tabular}

\section{b) Design (desain)}

Tahap ini dikenal dengan istilah membuat rancangan (blue print). Pada tahap desain, ditetapkan tujuan pembelajaran yang ingin dicapai, jenis software yang akan digunakan, bagaimana penggunaan media, serta rancangan dari multimedia interaktif yang akan dibuat.

Hasil analisis menetapkan media yang akan dibuat dan dikembangkan yaitu multimedia interaktif dengan menggunakan materi ciri-ciri makhluk hidup. Multimedia interaktif dipilih karena dalam multimedia interaktif tergabung ketiga aspek yaitu teks, gambar dan video. Selain itu juga terdapat pemberian umpan balik, media tidak hanya berjalan dalam satu arah.

Adapun untuk pemilihan aplikasi/software yang akan digunakan untuk mengembangkan multimedia ini peneliti memilih Microsoft Power Point. Aplikasi Microsoft Power Point dipilih karena kemudahan penggunaannya sehingga lebih efektif dalam pembuatan media yang membutuhkan waktu yang singkat dan cocok digunakan oleh guru di sekolah. Juga karena fitur yang disediakan oleh Microsoft Power Point lebih beragam dan mudah diaplikasikan. Rancangan awal dari multimedia yang akan dibuat adalah seperti yang tertera pada gambar 1 di bawah ini, terdiri dari empat menu utama yaitu belajar, praktikum, tes, dan kamus. Menu belajar berisi materi tentang ciri-ciri makhluk hidup. Menu praktikum berisi tentang kegiatan di luar kelas berupa pengamatan lingkungan sekitar. Menu tes berisi tentang soal-soal untuk menguji pemahaman siswa. Adapun menu kamus berisi penjelasan singkat dari beberapa kata yang sulit dimengerti maknanya. 


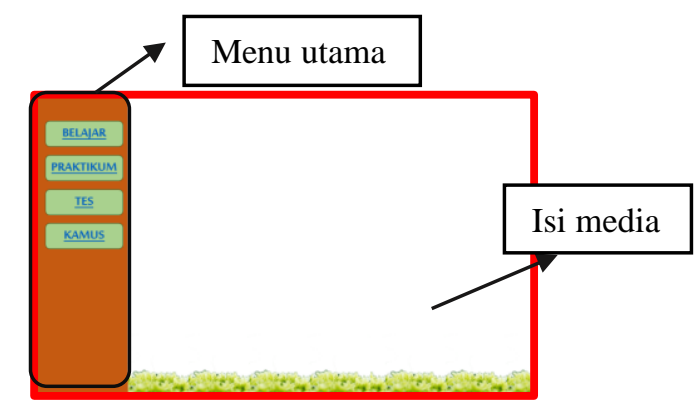

\section{Gambar 1. Rancangan awal multimedia interaktif}

\section{c) Development (pengembangan)}

Tahap pengembangan (development) merupakan proses mewujudkan rancangan yang telah dibuat. Kegiatan pada tahap ini meliputi kegiatan pengumpulan bahan/materi media pembelajaran berbasis multimedia interaktif, pengetikan, dan lain-lain. Bahan berupa gambar dikumpulkan dari internet. Adapun materi didapatkan dari berbagai buku mata pelajaran IPA yang relevan. Proses pembuatannya cukup sederhana, seperti pembuatan slide presentasi pada umumnya yakni memasukkan/menyisipkan gambar dan tulisan pada kolom yang disediakan. Yang membuat media ini berbeda dari slide presentasi biasa adalah kreativitas penggabungan animasi dan transisi, penggunaan gambar dibuat agak mencolok dan lebih banyak dibandingkan dengan penggunaan teks, serta keteraturan penggunaan menu action pada tab menu insert

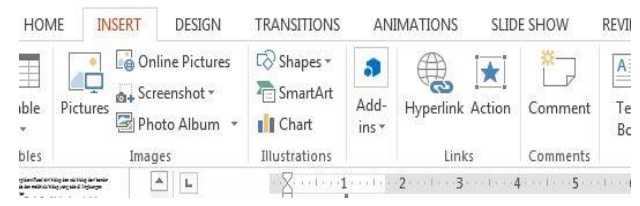

\section{Gambar 2. Tampilan menu insert pada tab menu}

Saat menu insert pada tab menu diklik, maka akan muncul beberapa sub menu, salah satunya yaitu sub menu action. Menu action ini untuk mengatur perpindahan slide ke slide lainnya dengan menggunakan link yang ada di halaman tersebut. Saat menu action diklik, maka akan muncul jendela seperti yang ada pada gambar 3 dibawah ini. Pada jendela tersebut, pada menu mouse clik, pilih hyperlink to. Lalu pilih ke slide mana perpindahan yang diinginkan. Kata/kalimat yang telah menggunakan menu action ditandai dengan garis bawah (underline) yang dimiliki oleh kata/kalimat tersebut, juga perubahan kursor yang berubah menjadi gambar jari jika kursor diarahkan pada kata/kalimat tersebut.

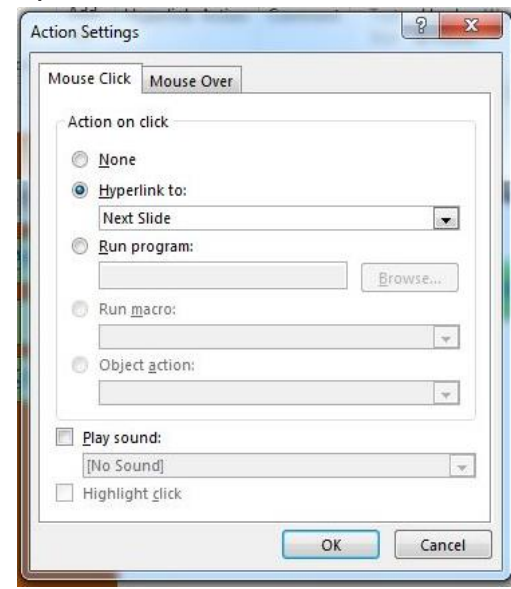

Gambar 3. Tampilan jendela menu Action 
p-ISSN 2621-5527

e-ISSN 2621-5535
Pengembangan Multimedia Interaktif pada Pembelajaran Biologi untuk Meningkatkan Kemampuan Kognitif Siswa Kelas VII SMPLB Tunarungu (hlm. 24-37)

Berikut ini beberapa tampilan dari slide yang telah dikembangkan

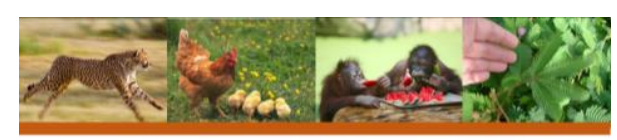

\section{CIRI-CIRIMAKHLUK HIDUP}

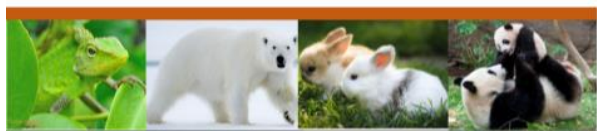

\section{Gambar 4. Tampilan halaman awal multimedia interaktif}

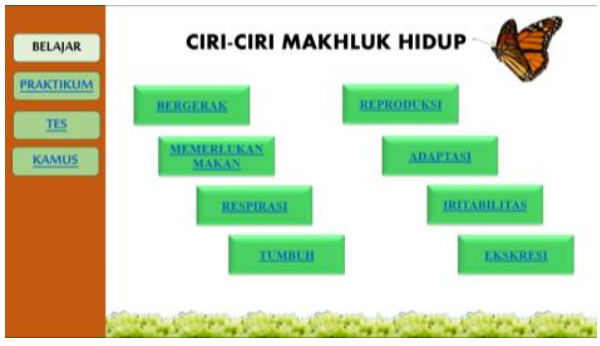

Gambar 5. Tampilan halaman utama materi

Halaman utama dari materi berisi judul sub materi ciri-ciri makhluk hidup. Tiap-tiap sub materi merupakan link untuk menuju ke materi yang dipilih.

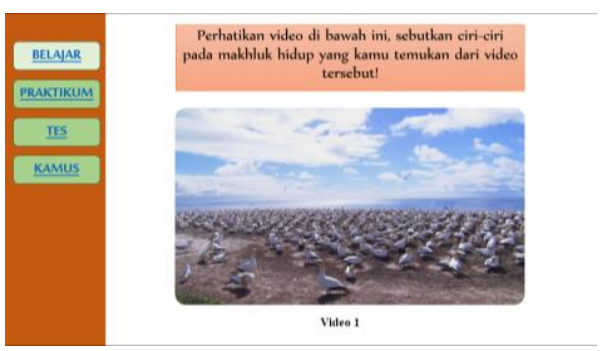

Gambar 6. Tampilan halaman yang berisi video

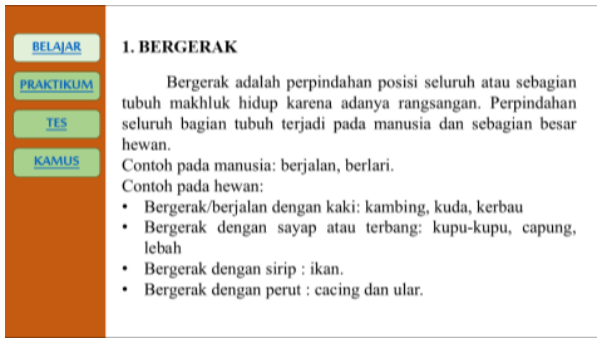

Gambar 7. Tampilan halaman yang berisi materi 

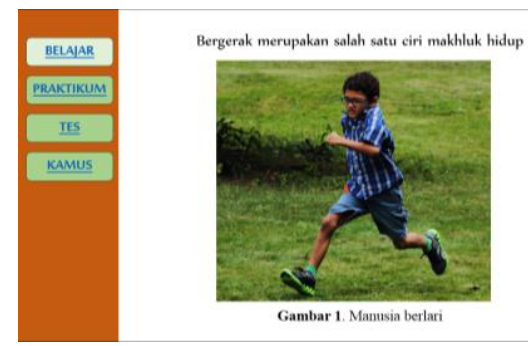

Gambar 7. Tampilan halaman yang berisi gambar

Tabel 5. Hasil Angket Validasi

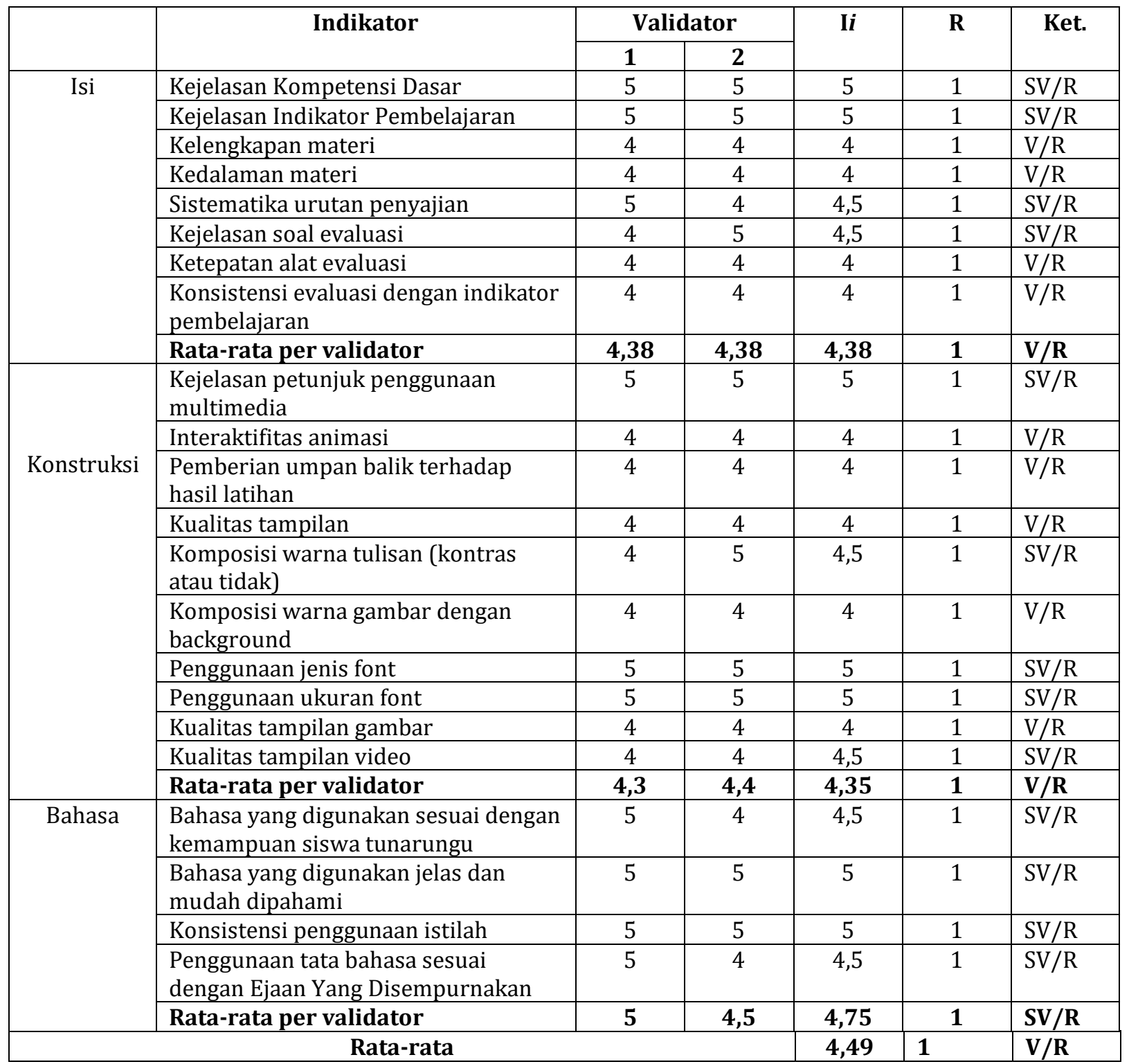

Keterangan:

$$
\begin{array}{ll}
\mathrm{SV} & =\text { sangat valid }(4.5 \leq \bar{V} \leq 5) \\
\mathrm{V} & =\text { valid }(3.5 \leq \bar{V}<4.5) \\
\mathrm{CV} & =\text { cukup valid }(2.5 \leq \bar{V}<3.5) \\
\mathrm{KV} & =\text { kurang valid }(1.5 \leq \bar{V}<2.5) \\
\mathrm{TV} & =\text { tidak valid }(\bar{V}<1.5)
\end{array}
$$




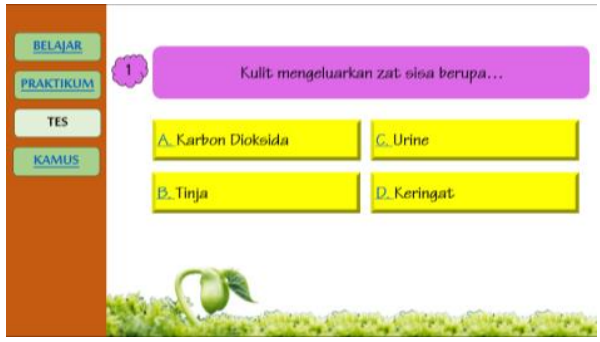

\section{Gambar 9. Tampilan halaman yang berisi soal evaluasi}

\section{d) Implementation (implementasi)}

Tahap implementasi (implementation) merupakan tahap penerapan media dalam pembelajaran di dalam kelas. Hasil pengembangan terlebih dahulu diperiksa oleh validator sebelum diterapkan dalam pembelajaran di kelas. Validasi multimedia interaktif dilakukan oleh dua orang validator ahli yaitu Drs. H. Abdul Muis M. Si dan Drs. H. Hamka L, M.S. Angket validasi yang digunakan dalam tahap ini menggunakan skala Likert dengan 5 kriteria penilaian yaitu $1=$ sangat kurang; $2=$ kurang; 3 = cukup; $4=$ baik; 5 sangat baik.

Untuk mengetahui konsistensi dari serangkaian pengukuran atau serangkaian alat ukur maka dilakukan uji realibilitas. Penentuan realibilitas instrument, digunakan konsep percentage of agreements oleh Grinnell dalam (Hobri.2010) dengan ketentuan agreement jika selisih penilaian 2 orang pengamat sama dengan 0 atau 1 maka nilai percentage of agreements $(\mathrm{R})=1$. Hal ini dilakukan dengan dengan asumsi bahwa toleransi penilaian antar pengamat maksimal 1 , karena selisih 1 masih berada kategori penilaian yang relatif sama. Berikut hasil angket validasi dari multimedia interaktif yang telah dikembangkan.

Beberapa bagian dari multimedia diperbaiki sesuai dengan saran dari validator ahli pada tahap validasi. Uji validasi dilakukan sebanyak 4-5 kali untuk masing-masing validator ahli hingga menghasilkan media yang layak utuk digunakan dalam penelitian. Setelah tahap validasi, multimedia ini selanjutnya diujicobakan di sekolah. Sekolah tempat uji coba yang dipilih yaitu kelas VII SLB Negeri 1 Makassar yang berlokasi di jalan Daeng Tata Raya.

\section{e) Evaluation (evaluasi)}

Tahap evaluasi adalah proses untuk melihat kevalidan, kepraktisan dan keefektifan dari media yang telah dikembangkan. Tahap evaluasi bisa dilakukan pada setiap empat tahap di atas, yang disebut evaluasi formatif, karena tujuannya untuk kebutuhan revisi. Tahap evaluasi pada penelitian ini menggunakan angket. Pada tahap evaluasi juga digunakan skala Likert dengan 5 kriteria penilaian yaitu yaitu 1=sangat kurang; $2=$ kurang; $3=$ cukup; $4=$ baik; 5 sangat baik. Hasil evaluasi nilai kepraktisan dari multimedia interaktif yang telah dikembangkan berdasarkan penilaian dari guru mata pelajaran adalah sebagai berikut: 
Tabel 6. Hasil Angket Nilai Kepraktisan (Guru)

\begin{tabular}{|c|c|c|c|c|}
\hline Aspek & $\begin{array}{l}\text { Indikator } \\
\end{array}$ & Ii & $\mathbf{A i}$ & Ket. \\
\hline \multirow[t]{2}{*}{ Keantusiasan siswa } & $\begin{array}{l}\text { Proses belajar mengajar dengan menggunakan multimedia } \\
\text { interaktif membuat siswa semakin antusias dalam mengikuti } \\
\text { pelajaran }\end{array}$ & 5 & \multirow[t]{2}{*}{4,5} & \multirow[t]{2}{*}{$\mathrm{T}$} \\
\hline & $\begin{array}{l}\text { Pengunaan multimedia interaktif mengurangi kebosanan } \\
\text { siswa dalam belajar }\end{array}$ & 4 & & \\
\hline \multirow{2}{*}{$\begin{array}{l}\text { Kemudahan } \\
\text { pengoperasian }\end{array}$} & Software yang digunakan mudah diinstal & 4 & \multirow[t]{2}{*}{4} & \multirow[t]{2}{*}{$\mathrm{T}$} \\
\hline & Mudah dioperasikan dalam proses belajar mengajar & 4 & & \\
\hline \multirow[t]{2}{*}{ Kemenarikan } & $\begin{array}{l}\text { Multimedia interaktif memiliki tampilan yang menarik } \\
\text { perhatian siswa untuk belajar }\end{array}$ & 4 & \multirow[t]{2}{*}{4} & \multirow[t]{2}{*}{$\mathrm{T}$} \\
\hline & $\begin{array}{l}\text { Materi dan bahasa yang digunakan menarik dan mudah } \\
\text { dipahami sehingga tidak memerlukan penjelasan yang } \\
\text { panjang untuk memahamkan kepada siswa }\end{array}$ & 4 & & \\
\hline \multirow[t]{2}{*}{ Keinteraktifan } & Multimedia interaktif bersifat interaktif & 4 & \multirow[t]{2}{*}{4} & \multirow[t]{2}{*}{$\mathrm{T}$} \\
\hline & Sistem navigasi halaman yang teratur & 4 & & \\
\hline \multirow[t]{2}{*}{$\begin{array}{l}\text { Keterlaksanaan sintaks } \\
\text { PBM }\end{array}$} & $\begin{array}{l}\text { Cakupan isi dan materi dalam multimedia interaktif sudah } \\
\text { sesuai dengan RPP dan silabus yang ada }\end{array}$ & 4 & \multirow[t]{2}{*}{4} & \multirow[t]{2}{*}{$\mathrm{T}$} \\
\hline & $\begin{array}{l}\text { Multimedia interaktif membuat proses belajar mengajar } \\
\text { menjadi lancer }\end{array}$ & 4 & & \\
\hline \multirow[t]{2}{*}{$\begin{array}{l}\text { Pemanfaatan media } \\
\text { dalam pembelajaran }\end{array}$} & $\begin{array}{l}\text { Multimedia interaktif membantu guru dalam proses belajar } \\
\text { mengajar }\end{array}$ & 4 & \multirow[t]{2}{*}{4} & \multirow[t]{2}{*}{$\mathrm{T}$} \\
\hline & $\begin{array}{l}\text { Multimedia interaktif dapat membantu meningkatkan aspek } \\
\text { kognitif siswa }\end{array}$ & 4 & & \\
\hline \multicolumn{3}{|c|}{ Rata-rata } & 4,08 & $\mathbf{T}$ \\
\hline
\end{tabular}

Tabel 7. Hasil Angket Nilai Kepraktisan (Siswa)

\begin{tabular}{|c|c|c|c|c|c|c|c|c|}
\hline \multirow[t]{2}{*}{ No. } & \multirow[t]{2}{*}{ Aspek penilaian } & \multicolumn{5}{|c|}{ Frekuensi } & \multirow{2}{*}{$\begin{array}{l}\text { Rata- } \\
\text { rata }\end{array}$} & \multirow[t]{2}{*}{ Ket. } \\
\hline & & 1 & 2 & 3 & 4 & 5 & & \\
\hline 1 & $\begin{array}{l}\text { Media pembelajaran multimedia interaktif sangat } \\
\text { menyenangkan }\end{array}$ & & & & 3 & 5 & 4,63 & $\mathrm{~T}$ \\
\hline 2 & $\begin{array}{l}\text { Media pembelajaran multimedia interaktif dapat } \\
\text { meingkatkan semangat belajar saya }\end{array}$ & & & 2 & 3 & 3 & 4,13 & $\mathrm{~T}$ \\
\hline 3 & $\begin{array}{l}\text { Media pembelajaran multimedia interaktif membuat } \\
\text { pelajaran tidak monoton }\end{array}$ & & & 1 & 6 & 1 & 4,00 & $\mathrm{~T}$ \\
\hline 4 & $\begin{array}{l}\text { Media pembelajaran multimedia interaktif membantu } \\
\text { saya dalam memahami materi }\end{array}$ & & & & 2 & 6 & 4,75 & $\mathrm{~T}$ \\
\hline 5 & $\begin{array}{l}\text { Media pembelajaran multimedia interaktif } \\
\text { memudahkan kami dalam belajar }\end{array}$ & & & & 3 & 5 & 4,63 & $\mathrm{~T}$ \\
\hline 6 & $\begin{array}{l}\text { Media pembelajaran multimedia interaktif membuat } \\
\text { pelajaran menarik untuk dipelajari }\end{array}$ & & & 1 & 5 & 2 & 4,13 & $\mathrm{~T}$ \\
\hline 7 & $\begin{array}{l}\text { Media pembelajaran multimedia interaktif membuat } \\
\text { saya lebih terampil }\end{array}$ & & & 1 & 7 & & 3,88 & $\mathrm{~T}$ \\
\hline 8 & $\begin{array}{l}\text { Multimedia interaktif membuat saya termotivasi dalam } \\
\text { belajar }\end{array}$ & & & & 2 & 6 & 4,75 & $\mathrm{~T}$ \\
\hline 9 & $\begin{array}{l}\text { Multimedia interaktif menghilangkan kebosanan saya } \\
\text { dalam belajar }\end{array}$ & & & & 6 & 2 & 4,25 & $\mathrm{~T}$ \\
\hline 10 & $\begin{array}{l}\text { Belajar dengan menggunakan multimedia interaktif } \\
\text { membuat saya tidak mengantuk ketika pembelajaran } \\
\text { berlangsung }\end{array}$ & & & & 4 & 4 & 4,50 & $\mathrm{~T}$ \\
\hline & Rata-rata & & & & & & 4,36 & $\mathbf{T}$ \\
\hline
\end{tabular}

Keterangan:

$\begin{array}{llll}\mathrm{SR} & =\text { sangat rendah } & \mathrm{T} & =\text { tinggi } \\ \mathrm{R} & =\text { rendah } & \mathrm{ST} & =\text { sangat tinggi } \\ \mathrm{S} & =\text { sedang } & & \end{array}$


Nilai keefektifan dari multimedia interaktif yang telah dikembangkan dievaluasi dengan menggunakan skor N-Gain. Skor N-Gain merupakan perbandingan dari skor pretest dan skor posttest. Adapun hasil dari skor N-gain adalah sebagai berikut:

Tabel 8. Skor N-Gain

\begin{tabular}{|c|c|c|c|c|}
\hline No. & $\begin{array}{c}\text { Nama } \\
\text { Siswa }\end{array}$ & Nilai Pre test & $\begin{array}{c}\text { Nilai Post } \\
\text { Test }\end{array}$ & $\begin{array}{c}\text { N- } \\
\text { Gain }\end{array}$ \\
\hline 1 & LQ & 50 & 80 & 0,60 \\
\hline 2 & KK & 70 & 70 & 0,00 \\
\hline 3 & NS & 70 & 80 & 0,33 \\
\hline 4 & NK & 50 & 90 & 0,80 \\
\hline 5 & KJ & 70 & 100 & 1,00 \\
\hline 6 & SI & 70 & 70 & 0,00 \\
\hline 7 & SA & 60 & 70 & 0,25 \\
\hline 8 & AF & 70 & 70 & 0,00 \\
\hline 9 & BW & 50 & 80 & 0,60 \\
\hline \multicolumn{2}{|r|}{ Rata-rata } & $\mathbf{6 2 , 2 2}$ & $\mathbf{7 8 , 8 9}$ & $\mathbf{0 , 4 0}$ \\
\hline
\end{tabular}

\section{Pembahasan}

Media pembelajaran multimedia interaktif dikembangkan dengan mengacu pada model pengembangan ADDIE (Analyze, Design, Development, Implementation, and Evaluation). Model ini dipilih karena model pengembangan ini lebih rasional dan lebih lengkap. Selain itu, model ini juga dapat digunakan untuk berbagai macam bentuk pengembangan produk seperti model, strategi pembelajaran, metode pembelajaran, media dan bahan ajar.

\section{a) Kevalidan}

Sebelum multimedia interaktif ini diujicobakan, terlebih dahulu divalidasi oleh para ahli. Hasil analisis validasi menunjukkan bahwa rata-rata kevalidan multimedia interaktif yang dikembangkan adalah sebesar 4,49. Hal ini menunjukkan bahwa multimedia interaktif tersebut "valid", sehingga layak untuk digunakan dalam poses belajar mengajar di kelas. Dalam tahap validasi ini, ada tiga aspek yang dinilai, yaitu aspek isi, aspek konstruksi dan aspek bahasa.

b) Isi

Aspek isi dari multimedia interaktif ini memiliki nilai rata-rata 4,38 yang berarti tergolong "valid". Indikator dari aspek isi meliputi kejelasan kompetensi dasar, kejelasan indikator pembelajaran, kelengkapan materi, kedalaman materi, sistematika urutan penyajian, kejelasan soal evaluasi, ketepatan alat evaluasi, konsistensi evaluasi dengan indikator pembelajaran. Kejelasan kompetensi dasar dan indikator mendapatkan nilai 5 dari masingmasing validator, yang berarti "sangat valid". Adapun dari segi materi, baik kelengkapan maupun kedalaman, mendapatkan nilai 4 sehingga tergolong "valid".

\section{c) Konstruksi}

Aspek konstruksi dari multimedia interaktif ini memiliki nilai rata-rata 4,35 sehingga tergolong "valid". Indikator yang dinilai yaitu kejelasan petunjuk penggunaan media, interaktifitas animasi, pemberian umpan balik terhadap hasil latihan, kualitas tampilan, komposisi warna tulisan (kontras atau tidak), komposisi warna gambar dengan background, penggunaan jenis font, penggunaan ukuran font, kualitas tampilan gambar, dan kualitas tampilan video.

\section{d) Bahasa}

Aspek bahasa dari multimedia interaktif ini memiliki nilai rata-rata 4,75 sehingga tergolong "valid". Adapun indikator yang dinilai dari aspek ini adalah apakah bahasa yang digunakan seseuai dengan kemampuan siswa tunarungu, apakah bahasa yang digunakan jelas 
dan mudah dipahami, konsistensi penggunaan istilah, serta penggunaan tata bahasa yang sesuai dengan Ejaan Yang Disempurnakan.

\section{e) Kepraktisan}

Kepraktisan multimedia interaktif yang dikembangkan ini juga dinilai berdasarkan hasil angket. Angket yang digunakan ada dua, yakni angket untuk guru dan angket untuk siswa. Kedua angket ini dibagikan setelah proses pembelajaran selesai. Hasil angket nilai kepraktisan berdasarkan penilaian dari guru memiliki nilai rata-rata 4,08 sehingga tergolong tinggi. Aspek yang dinilai untuk melihat tingkat kepraktisan multimedia ini ada 6 aspek, yaitu aspek keantusiasan siswa, kemudahan pengoperasian, kemenarikan, keinteraktifan, keterlaksanaan sintaks PBM, dan pemanfaatan media dalam pembelajaran. Dari keenam aspek tersebut, semuanya mendapatkan nilai rata-rata 4 kecuali aspek keantusiasan siswa. Aspek keantusiasan siswa ini mendapatkan nilai rata-rata 4,5.

Hasil angket nilai kepraktisan dari siswa memiliki nilai rata-rata 4,36 juga termasuk kategori tinggi. Aspek yang dinilai untuk melihat tingkat kepraktisan multimedia interaktif berdasarkan penilaian siswa ada 10 aspek, yaitu: 1)Multimedia interaktif sangat menyenangkan, dengan nilai rata-rata 4,63 sehingga tergolong tinggi; 2) Media pembelajaran multimedia interaktif dapat meningkatkan semangat belajar saya, dengan nilai rata-rata 4,$13 ; 3$ ) Media pembelajaran multimedia interaktif membuat pelajaran tidak monoton, dengan nila ratarata 4,00 ; 4) Media pembelajaran multimedia interaktif membantu siswa dalam memahami materi pelajaran, dengan nila rata-rata 4,75 ; 5) Media pembelajaran multimedia interaktif memudahkan siswa dalam belajar, dengan nilai rata-rata 4,63 ; 6) Media pembelajaran multimedia interaktif membuat pelajaran menarik untuk dipelajari dengan nilai rata-rata 4,13; 7) Multimedia interaktif membuat siswa lebih terampil, dengan nilai rata-rata 3,88 ; 8) Multimedia interaktif membuat siswa termotivasi dalam belajar, dengan skor rata-rata 4,75; 9) Multimedia interaktif menghilangkan kebosanan siswa dalam, belajar dengan nilai rata-rata 4,25 ; 10) Belajar dengan menggunakan multimedia interaktif membuat siswa tidak mengantuk ketika pembelajaran sedang berlangsung, dengan nilai rata-rata 4,50.

\section{f) Keefektifan}

Multimedia interaktif yang telah dikembangkan dikatakan efektif apabila ada peningkatan aspek kognitif siswa setelah uji coba. Keefektiffan multimedia interaktif yang dikembangkan dinilai berdasarkan skor N-gain. Skor N-gain diperoleh berdasarkan nilai pretest dan posttest siswa. Berdasarkan tabel 4.5 tentang skor $\mathrm{N}$-Gain dari 9 orang siswa, 4 diantaranya dengan hasil skor $\mathrm{N}$-Gain kategori rendah $(0,30 \geq \mathrm{g}), 3$ orang dengan kategori sedang $(0,70 \geq \mathrm{g} \geq$ $0,30)$ dan 2 orang dengan kategori tinggi $(g>0,70)$. Dari hasil analisis data, diperoleh rata-rata skor N-Gain sebanyak 0,40 sehingga tergolong kategori sedang. Dari skor N-Gain tersebut dapat diketahui bahwa multimedia interaktif yang dikembangkan dapat meningkatkan kemampuan kognitif siswa.

\section{Kesimpulan}

Berdasarkan hasil penelitian dan pembahasan yang telah diuraikan sebelumnya maka dapat disimpulkan bahwa media pembelajaran multimedia interaktif yang telah dikembangkan telah memenuhi kriteria kevalidan dan tergolong kategori valid. Media pembelajaran multimedia interaktif yang telah dikembangkan telah memenuhi kriteria kepraktisan dan tergolong kategori tinggi. Media pembelajaran multimedia interaktif yang telah dikembangkan tergolong dalam kategori efektif dengan adanya peningkatan aspek kognitif siswa berdasarkan skor N-Gain yang tergolong dalam kategori sedang.

\section{Referensi}

Asrori, M. (2007). Psikologi Pembelajaran. Bandung. CV Wacana Prima. 
Fajrianto, R \& Irawan. (2012). Perancangan Media Pembelajaran Interaktif Mata Pelajaran IPA untuk Siswa KelasVIII SMPLB Tunarungu dengan Materi Memahami Sistem dalam Tubuh Manusia. Jurnal Teknik POMITS. 1 (1), 1-4.

Haenudin. (2013). Pendidikan Anak Berkebutuhan Khusus Tunarungu. Jakarta. PT. Luxima Metro Media.

Hallahan, D.P. \& Kauffman, J.M .(2006). Exceptional Learners, An Introduction to Special Education. Tenth Edition, Boston. Allyn \& Bacon.

Pariatin, Y. \& Yuda, Z.A. (2014). Perancangan Media Pembelajaran Interaktif Mata Pelajaran Pkn untuk Penyandang Tunarungu Berbasis Multimedia (Studi kasus di Kelas VII SMPLB Negeri Garut Kota). Jurnal Algoritma. 11 (1).

Poedjiastoeti, S. (2012). "Kit Kimia dengan Strategi Writing to Learn untuk Siswa SMALB Tunarungu". Prosiding Seminar Nasional Kimia UNESA. Surabaya.

Somantri, S. (2007). Psikologi Anak Luarbiasa. Bandung. Refika Aditama.

Sunarto \& Agung, H. (2008). Perkembangan Peserta Didik. Jakarta. Rineka Cipta.

Sri Rahmawati M
Jurusan Biologi. Fakultas Matematika dan Ilmu Pengetahuan Alam, Universitas Negeri Makassar

email: sri.rahmawati1793@gmail.com 